\title{
Apuntes
}

\section{Sedes Web de plazas de toros andaluzas}

Susana Limón Rodriguez

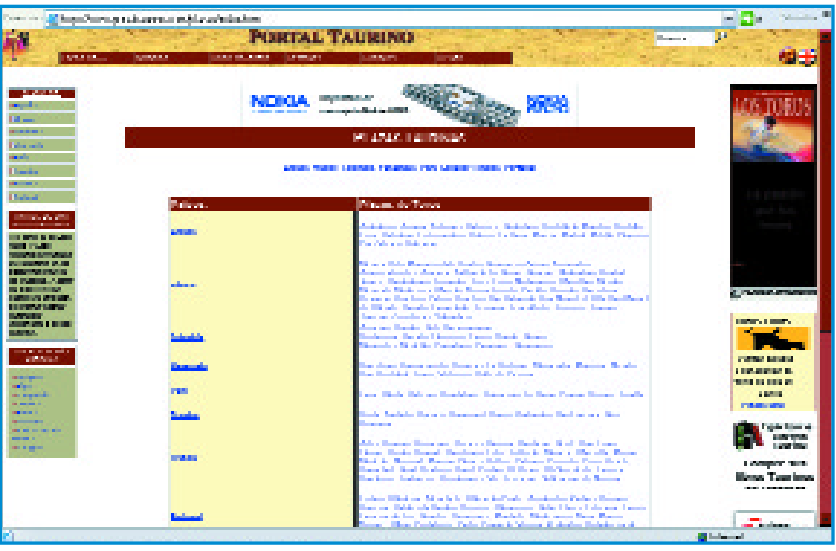

\section{Portal Taurino}

http://portaltaurino.com/portal.htm

Este portal oferta contenidos especializados sobre el mundo del toro, con noticias de actualidad sobre la tauromaquia, con bases de datos sobre ganaderías, novilleros, empresarios, rejoneadores, plazas de toros de España y el extranjero, entre otros.

Centrándonos en la información específica sobre las plazas de toros, tenemos un amplio apartado sobre las principales plazas de España clasificadas por Autonomías, con enlace añadido a las principales plazas del mundo: México, Colombia, Venezuela o Portugal, entre otras.

En el caso de Andalucia se encuentran clasificadas por provincias, y dentro de las provincias, encontramos un primer nivel de información sobre las plazas de cada capital y enlaces a todos los municipios de esa provincia que cuenten con alguna plaza. La información sobre las plazas viene acompañada normalmente de imágenes y presenta en algunos casos entre sus datos vínculos acerca de ganaderías o toreros que han influido ampliamente en la historia de las mismas.

\section{Comisión Consultiva Nacional de Asuntos Taurinos www.mir.es/toros/plazas/andaluci.htm}

En esta página del Ministerio del Interior aparece un listado de todas las plazas de toros de cada provincia, con datos sobre su categoría, aforo y propiedad.

\section{Monumentalia} www.monumentalia.net

En esta sede web, en el apartado plazas, se describen plazas de toros entre las que se encuentran Ronda (Cádiz), Campofrío (Huelva), Granada, Maestranza de Sevilla, Málaga y Úbeda (Jaén).

Además de estas referencias generales, algunas provincias cuentan con páginas propias acerca de sus plazas de toros:

\section{Toros en Cádiz}

http://infocadiz.com/Toros

Informa sobre las plazas de la provincia o plazas para la historia, ganaderías o fotografías relacionadas con esta temática.

\section{Plaza de Toros de la Merced www.columbus-digital.com/toros.la.merced}

Con información sobre el mundo taurino, los espectáculos que en ella se celebran, las fiestas colombinas y otros.

\section{Plazas en Málaga}

www.platayoro.org/lasplazas

Ofrece una relación de las principales plazas de toros de Málaga (Málaga capital, Antequera, Benalmádena, Estepona, Fuengirola, Marbella, Mijas, Ronda y Torremolinos), acompañadas de documentación gráfica. A ello se añaden otros enlaces de interés sobre el mundo taurino, así como de ganaderías o toreros, entre otros.

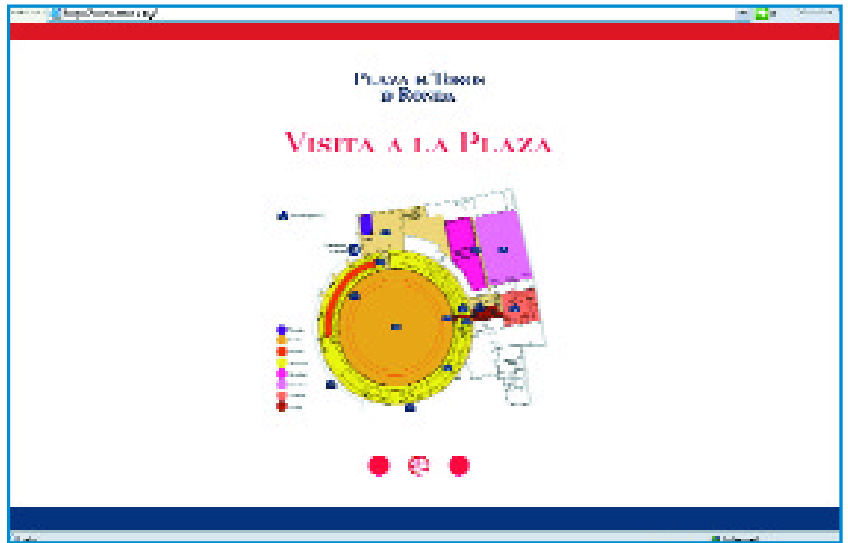

\section{Real Maestranza de Caballería de Ronda www.rmcr.org}

Su historia, la primera corrida de toros que en ella se celebró, las dinastías de toreros de Ronda, las corridas goyescas, una visita a la misma a través de un plano interactivo, así como una amplia información sobre su Museo Taurino se incluyen esta sede web.

\section{Real Maestranza de Caballería de Sevilla www.realmaestranza.com}

Entre sus contenidos apreciamos tres apartados diferenciados: información sobre la Real Maestranza (apuntes históricos, la plaza en la actualidad, actividades y mecenazgo y bibliografía), información sobre la Plaza de toros (historia, arquitectura y temporada actual) e información sobre el Museo taurino (horario y contenidos, y listado de publicaciones en venta, de libros y obra gráfica especializada). 